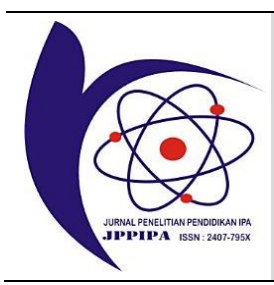

\title{
Development of Augmented Reality Flashcard Media to Improve the Ability of Grade IV Elementary School Students in Reading Understanding of Alternative Energy Source Materials
}

\author{
Novi Listiyani ${ }^{*}$, Sholeh Hidayat ${ }^{2}$, Lukman Nulhakim ${ }^{3}$ \\ ${ }^{1}$ Educational Technology Studi Program Postgraduate, Sultan Ageng Tirtayasa University, Indonesia. \\ ${ }^{2}$ Education Doctoral Study Program Coordinator, Sultan Ageng Tirtayasa University, Indonesia. \\ ${ }^{3}$ Head of Science Education, Sultan Ageng Tirtayasa University, Indonesia.
}

DOI: $10.29303 /$ jppipa.v7i4.861

\section{Article Info}

Received: August 5th 2021

Revised: October 10th 2021

Accepted: October 20th, 2021

\begin{abstract}
The use of information and communication technology such as social media has become a necessity as well as a demand in the global era. Therefore, it is necessary to develop various creative and innovative educational models so that the educational process does not seem less interesting, monotonous, and boring so that it will limit the formation of the transfer of knowledge, which is the focus of research. The purpose of this research is how appropriate the development of augmented reality flashcard media is to improve the ability of fourth grade elementary school students to read comprehension of alternative energy source materials. This research uses the Research and Development (R\&D) method with the ADDIE development model. The results obtained are that this development research creates a product in the form of an augmented reality flashcard media which is designed as an android-based application. In the feasibility test, the validation results of the material experts reached an average percentage of $85 \%$, which indicated very good qualifications. The validation results of media experts with an average percentage of $78 \%$, which indicated good qualifications.
\end{abstract}

Keywords: Learning media; Augmented reality flashcard; Alternative energy sources.

Citation: Listiyani, N., Hidayat, S., \& Nulhakim, L. (2021). Development of Augmented Reality Flashcard Media to Improve the Ability of Grade IV Elementary School Students in Reading Understanding of Alternative Energy Source Materials. Jurnal Penelitian Pendidikan IPA, 7(4), 782-787. doi:https://doi.org/10.29303/jppipa.v7i4.861

\section{Introduction}

The development of science and technology so that the educational process as a system consisting of several components, namely objectives, content or materials, methods, media, and assessments, must be carried out systematically and systemically so that it is efficient and effective. Improving the quality of education will be achieved if the learning process held inside or outside the classroom is really effective and useful to achieve the expected knowledge, behavior, and skills. Because basically, the learning process is the core of the total educational process. Education is a conscious and planned effort to create a learning atmosphere and learning process so that students actively develop their potential to have religiousspiritual strength, self-control, personality, intelligence, noble character, and skills needed by themselves, society, nation, and state (Indonesian Law No.20 of 2003 on the National Education System).

Activities in education also need to take advantage of advances in science and technology in order to be able to achieve their goals effectively and efficiently. Therefore, it is necessary to develop various creative and innovative learning media. The role of the media in the educational process is very important because it will make the educational process more varied and not boring. The use of information technology in delivering information has developed rapidly (Haryani \& Triyono, 2017). Currently, the latest

\footnotetext{
*Email: novilistiyani.nl@gmail.com
} 
technology used in the delivery of information is Augmented Reality (AR) technology. In Augmented Reality technology, users can visualize objects or goods in three-dimensional form. Augmented Reality has the advantage of being interactive and real-time, so Augmented Reality is widely implemented in various fields. This time, researchers are trying to utilize Augmented Reality technology in education combined with picture cards or better known as flashcards, as a facility to improve students' ability to understand the content of a text in science learning alternative energy source materials.

\section{Method}

The method used in this research is research and development with the ADDIE development model. The learning technology center developed ADDIE at the University of Florida for the United States military service (Rayanto \& Sugianti, 2020). The educational philosophy for this application of ADDIE is that intentional learning should be student-centered, innovative, authentic, and inspirational (Branch, 2009). This statement shows that the learning design of the ADDIE Model is a student-centered, authentic, interactive, and inspiring learning process with the basic stages of learning that are innovative, effective, dynamic, and efficient. The ADDIE model learning design scheme forms a cycle consisting of 5 stages consisting of analysis (Analysis), design (Design), development (Development), implementation (Implementation), and evaluation (Evaluation). The five stages of the development procedure can be seen in the following chart.

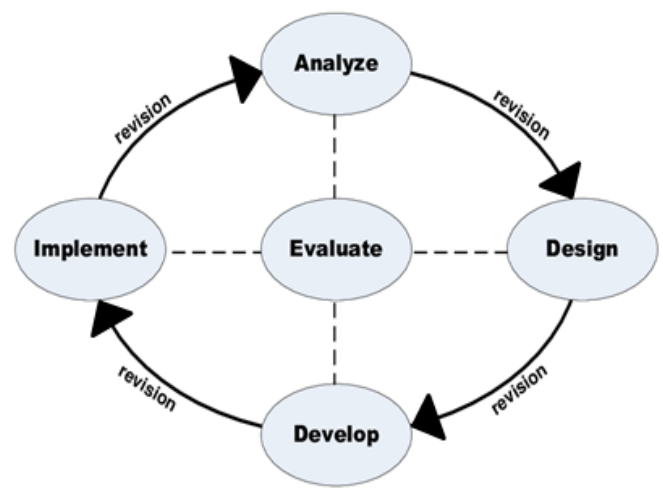

Figure 1. ADDIE Model Development Stage (Branch, 2009)

The development of Augmented Reality Flashcard media is based on the experience cone theory, which Dale first introduced in 1946 in his book entitled Audiovisual Methods in Teaching, about audiovisual methods in teaching. Dale's experience cone shows the experience gained in using media from the most concrete (at the very bottom) to the most abstract (at the very top).

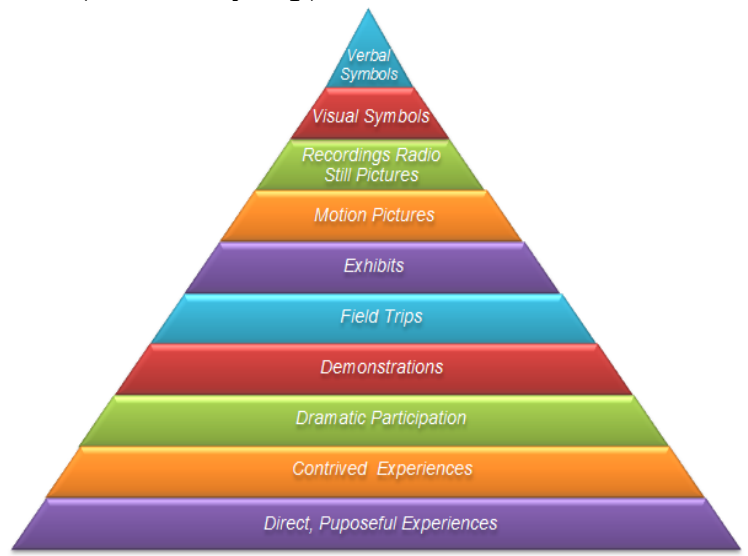

Figure 2. Cone of experiences (Kovalchick \& Dawson, 2004)

The 'cone of experiences' follows a onedimensional rationale, which leads from the concrete ('direct purposeful experiences') to the abstract ('verbal symbols') (Pachler, Bachmair, \& Cook, 2010). As shown in Figure 2.2, the statement of experiences or cones leads to a path that starts from concrete thoughts located at the lowest level to abstract thoughts located at the top level. Dale, as quoted (Sari, 2019), suggests the following categories of experience: (1) direct experience of intentional experience; (2) made-up experiences; (3) dramatic participation; demonstration; (5) field visits; (6) exhibitions; (7) moving pictures; (8) radio recordings, still images (audio with visual images); (9) visual symbols; (10) verbal symbols. Dale claims that the classification is simple and quality. This is also in line with the theory of cognitive development proposed by Piaget in (Honggowiyono, 2015).

Table 1. Stages of Cognitive Development

\begin{tabular}{lll}
\hline No & Development Stage & Age \\
\hline 1 & Sensori-motor stage & $0-2$ years \\
2 & Pre-operational stage & $2-7$ years \\
3 & Concrete operational stage & $7-11$ years \\
4 & Formal operational stage & $11-$ years \\
\hline
\end{tabular}

Based on table 1. it can be seen that children who are still in elementary school are generally between the ages of seven to eleven years. Thus, it shows that the age of the child is in the concrete operational stage. At this stage, children have the ability to do various jobs starting from something concrete or real whose form can be seen directly. Therefore, Augmented Reality Flashcard media was chosen as an application that will be developed to provide concrete learning experiences to students, keep students involved throughout the learning process, create a pleasant learning atmosphere so that it can make it easier for students to understand the contents of reading, in this case reading. This refers 
to the material of alternative energy sources. In addition, Media Augmented Reality Flashcard packaged in an application also offers a great opportunity to shake up a boring class.

This study aims to develop a product in the form of Augmented Reality Flashcard learning media in the form of an android-based application and test the feasibility of the product tested by material expert validators and media expert validators. The following are the criteria for processing data on the assessment of material experts and media experts proposed by Sugiyono (2015).

Table 2. Criteria for data processing assessment of material and media expert validators

\begin{tabular}{llll}
\hline No & Achievement Level & Qualification & Description \\
\hline 1 & $81-100 \%$ & Very Good & Very worthy/very valid/absolutely no need for revision \\
2 & $61-80 \%$ & Good & Worthy/ valid/ no revision needed \\
3 & $41-60 \%$ & Good Enough & Inappropriate/ Less valid/need revision \\
4 & $21-40 \%$ & Not Good & Inappropriate/ Invalid/Necessary Revision \\
5 & $<20 \%$ & Very Bad & Very unworthy/ very invalid/ need revision \\
\hline
\end{tabular}

An overview of the system in the application of the introduction of alternative energy sources contains the following development flow design:

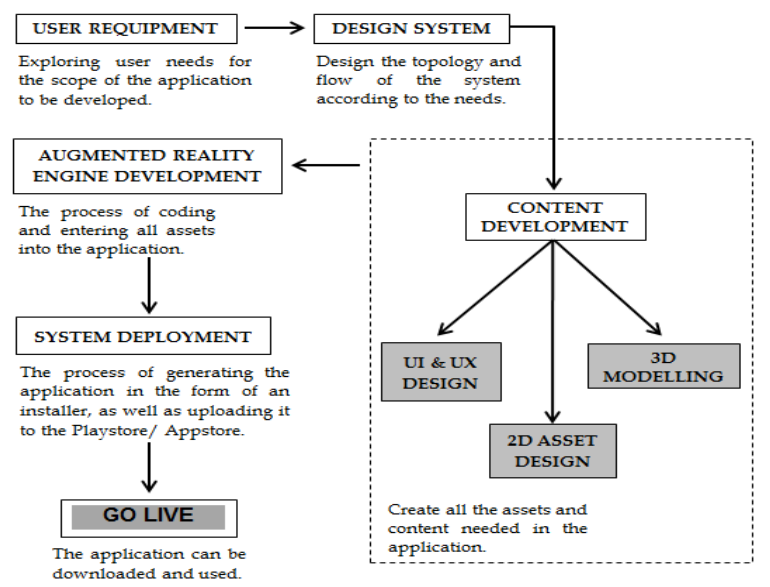

Figure 2. Modification of AR Flashcard Media Development Flowchart

\section{Result and Discussion}

Augmented Reality Flashcard media development is done using the ADDIE development model. Augmented Reality Flashcard media was tested on fourth-grade students at SD Negeri Serang 09. The following are the results of research on the development of Augmented Reality Flashcard media using the ADDIE model:

The first stage is analysis. In this section, there are two stages, namely the analysis of field conditions and the collection of reference materials, that will be discussed in augmented reality flashcard media development. The results of information about conditions in the field are obtained from observations carried out during the learning process.

The second stage designs. The design stage is the stage of making learning media which includes the formulation of media objectives, designing the topology and flow system, and determining the assets and content that will be used in the developed media in the form of an android-based application. The following is a visual display of the Augmented Reality Flashcard application layout:

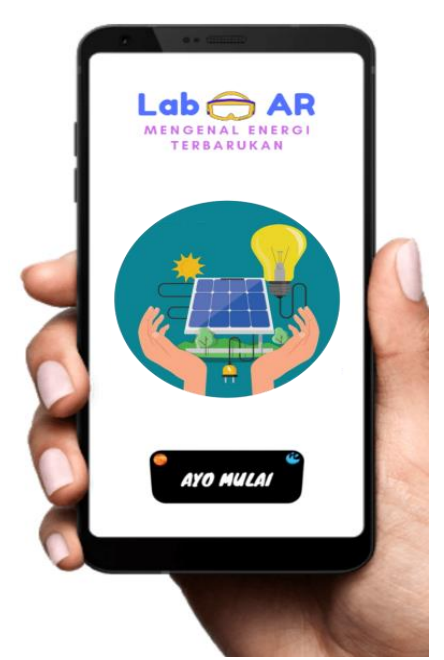

Figure 3. Application face layout

The following is a display of all layouts in the form of slides in the Augmented Reality Flashcard application:

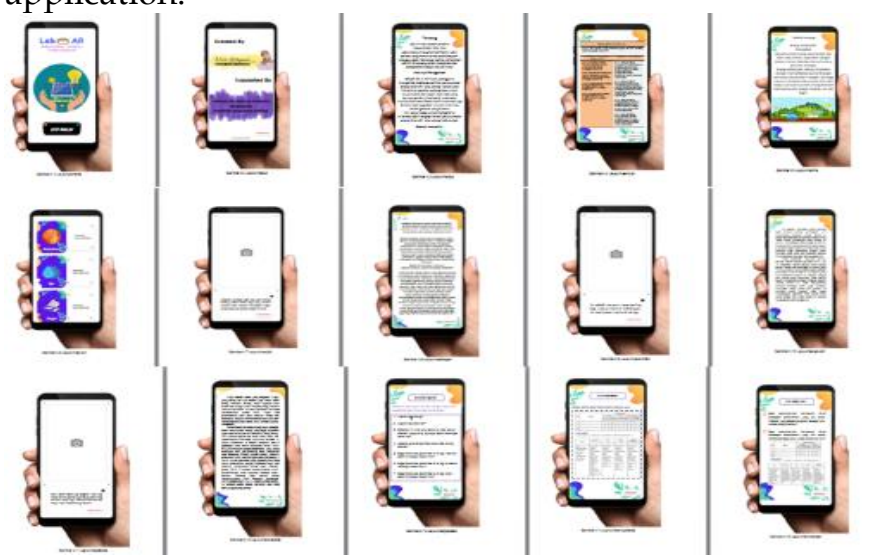

Figure 4. Application display 
The third stage is development. The development stage is the process of creating and developing augmented reality flashcard media from all components that have been prepared into a unified whole according to the layout designed using Canva, Blender 3D, and Unity applications.

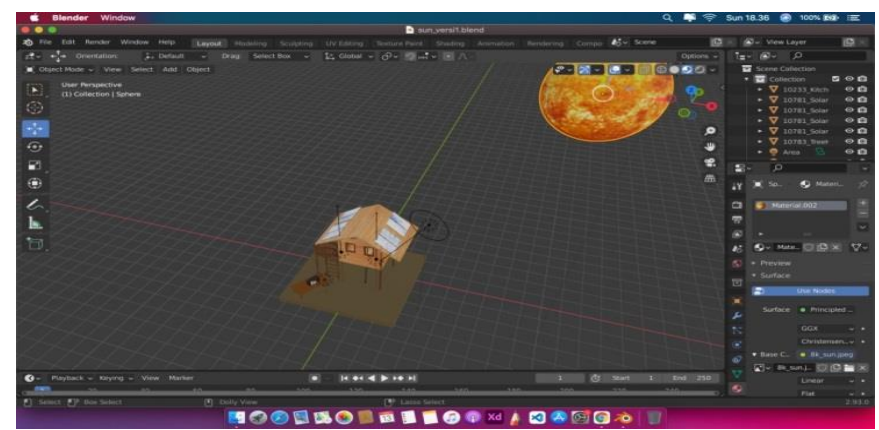

Figure 5. Preview of the final 3D animation (sun)

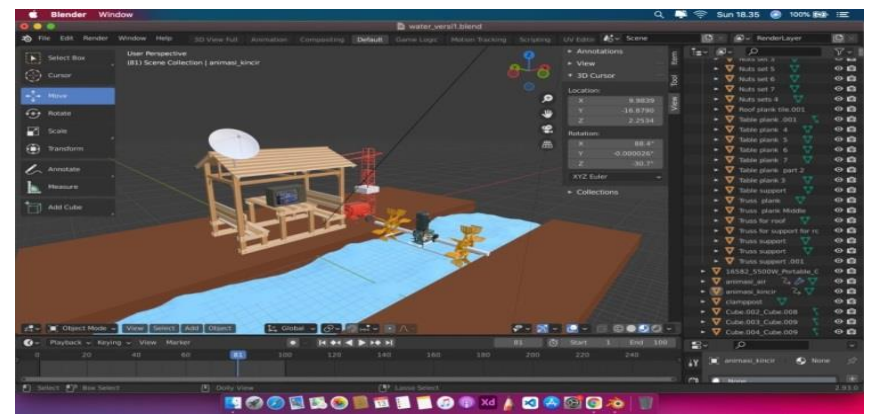

Figure 6. Preview of the final 3D animation (water)

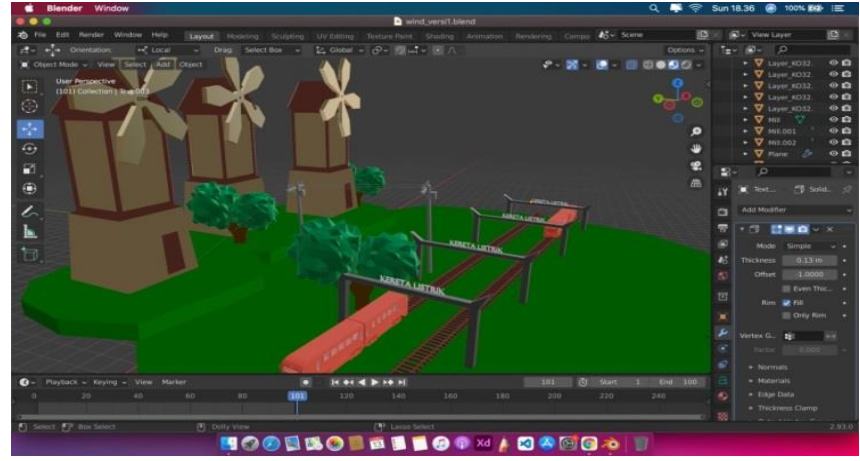

Figure 7. Preview of the final 3D animation (wind)

The fourth stage is implementation. At this stage, the augmented reality flashcard media that has been developed is then implemented in the learning process for the fourth-grade students of Serang 09 State Elementary School.

The fifth stage is evaluation. The evaluation carried out is an evaluation of the feasibility of the developed media. The development evaluation was carried out by material expert lecturers and media expert lecturers to determine the feasibility of learning media and measure whether the learning media resulting from the development were produced, disseminated, and used in Serang 09 State Elementary School.

Table 3. Recapitulation of material expert validation assessment

\begin{tabular}{|c|c|c|c|c|c|c|c|}
\hline No & Assessment Aspect & Total Item & Item Number & Score & Total Value & Average & Percentage \\
\hline 1 & $\begin{array}{l}\text { Compatibility with KI and KD } \\
\text { Subjects }\end{array}$ & 2 & $1 ; 2$ & $4 ; 4$ & 8 & 4 & $80 \%$ \\
\hline 2 & Material accuracy & 1 & 3 & 4 & 4 & 4 & $80 \%$ \\
\hline 3 & Material technique & 2 & $4 ; 5$ & $4 ; 5$ & 9 & 4.5 & $90 \%$ \\
\hline 4 & Serving completeness & 2 & $6 ; 7$ & $4 ; 5$ & 9 & 4.5 & $90 \%$ \\
\hline \multicolumn{4}{|c|}{ Total Score } & 30 & 30 & 17 & $340 \%$ \\
\hline \multicolumn{4}{|c|}{ Average } & 4.285 & 4.285 & 4.25 & $85 \%$ \\
\hline
\end{tabular}

Based on the recapitulation results of the assessment of the material expert validators, it can be seen in table 3 . Figure 8 shows that the average percentage reaches $85 \%$, which is in very good qualifications based on the criteria. The material contained in the augmented reality flashcard application is suitable for use in the learning process.

Table 4. Recapitulation of media expert validation assessment

\begin{tabular}{llllllll}
\hline No & Assessment Aspect & Total Item & Item Number & Score & Total Value & Average & Percentage \\
\hline 1 & User interface & 3 & $1 ; 2$ & $4 ; 4$ & 8 & 4 & $80 \%$ \\
2 & 2D asset design & 2 & $3 ; 4$ & $3 ; 4$ & 7 & 3.5 & $70 \%$ \\
3 & 3D Modelling & 1 & 5 & 4 & 4 & 4 & $80 \%$ \\
4 & Programming & 2 & $6 ; 7$ & $4 ; 4$ & 8 & 4 & $80 \%$ \\
5 & Media Display & 3 & $8 ; 9 ; 10$ & $4 ; 4 ; 4$ & 12 & 4 & 805 \\
Total Score & & & 39 & 39 & 3.5 & $390 \%$ \\
Average & & & 3.9 & 3.9 & 3.9 & $78 \%$ \\
\hline
\end{tabular}


Based on the results of the recapitulation of media expert assessments, it can be seen in table 4 . Figure 9 that the average percentage reaches $78 \%$, which is in good qualification based on the criteria. The augmented reality flashcard media developed is ready to be used by teachers and students in the learning process in the classroom.

The objectives of developing augmented reality flashcard media are as follows:

\section{Development of Augmented Reality Flashcard Media}

This study uses the Research and Development (R\&D) method using the ADDIE development model, which consists of several stages, namely: (1) Analysis; (2) Design; (3) Development; (4) Implementation; (5) Evaluation.

The first stage is analysis. In this section, there are two stages, namely in the form of analysis of field conditions and collection of reference materials, that will be the subject of discussion in the development of augmented reality flashcard media. The results of information about conditions in the field obtained from observations carried out during the learning process are also used as a reference as a needs analysis in conducting research. Research results also support that state that augmented reality flashcards have emerged as an important educational tool for language learning resources (Chen \& Chan, 2019).

The second stage designs. The design stage is the stage of designing learning media, which includes the formulation of the objectives of making media, designing the topology and flow system, and determining the assets and content that will be used in the developed media in the form of an android-based application.

The third stage is development. The development stage is the process of creating and developing augmented reality flashcard media from all the components that have been prepared into a unified whole according to the layout designed using Canva, Blender 3D, and Unity applications.

The fourth stage is implementation. At this stage, the augmented reality flashcard media developed is then implemented for the fourth-grade students of Serang 09 State Elementary School. This implementation aims to determine the effectiveness of the development of augmented reality flashcard media. From this stage, it will be known whether the effectiveness of the media used can improve the ability of fourth-grade elementary school students to read comprehension of alternative energy sources.

The fifth stage is evaluation. The evaluation carried out is an evaluation of the feasibility of the developed media. The development evaluation was carried out by material expert lecturers and media expert lecturers to determine the feasibility of learning media and measure whether the learning media resulting from the development were produced, disseminated, and used in Serang 09 State Elementary School.

\section{Eligibility of Augmented Reality Flashcard Media}

After the media the development stage is carried out, and the media is available, the next step is to test the feasibility of the media to be used in the learning process. The expert test was carried out in two stages: the material expert validation test and the media expert validation test. The results of the feasibility test data by material experts and media experts are described as follows:

\section{a. Material Expert Feasibility Data Results}

Based on the material expert validator's assessment results, a total score of 30 was obtained from the maximum total score of 35 . The percentage of eligibility was calculated by the formula for the percentage of eligibility. So, the feasibility results of the material on the augmented reality flashcard media are $85 \%$ which in table 2 is included in the very feasible category to be used as learning material that will be included in the augmented reality application. This is reinforced by the results of other studies that state that one of the stages that need to be considered in making learning media is determining the material to be included in the learning media (Mustaqim \& Kurniawan, 2017).

\section{b. Media Expert Eligibility Data Results}

Based on the results of the assessment of the media expert validator, a total score of 39 was obtained from the maximum total score of 50 . The same formula calculated the percentage of eligibility as the calculation of the results of the material expert validation. So, the results obtained by the media feasibility are $78 \%$ which in table 2 is included in the category of eligibility to be used as learning media. This is also in line with the statement that learning media can enhance student learning processes in learning, which is expected to enhance the learning outcomes achieved (Sudjana \& Rivai, 2010:2).

\section{Conclusion}

Based on the development of augmented reality flashcard media to improve the ability of fourth-grade elementary school students in reading understanding of alternative energy source material and the discussion of research results that have been discussed in the previous chapter, it can be concluded as follows: The 
research conducted is development research by going through five stages using the ADDIE development model. This development research produces a product in the form of augmented reality flashcard learning media. Based on the validation of material experts and media expert validation, it can be seen that the results of the recapitulation of the material expert validation assessment have an average percentage of $85 \%$, which indicates very good qualifications. The recapitulation results of the media expert's validation assessment have an average percentage of $78 \%$, which shows good qualifications.

\section{Acknowledgments}

The researcher would like to thank the stakeholders who have supported both morally and materially during the research process. In addition, the results of the development of augmented reality flashcard media are expected to be used in science learning so that it will make it easier for students to understand alternative energy sources.

\section{References}

Branch, R. M. (2009). Instructional Design: The ADDIE Approach. Springer. https://doi.org/10.1007/9780-387-09506-6

Chen, R. W., \& Chan, K. K. (2019). Using Augmented Reality Flashcards to Learn Vocabulary in Early Childhood Education. Journal of Educational Computing Research, 57(7), 1812-1831. https://doi.org/10.1177/0735633119854028

Haryani, P., \& Triyono, J. (2017). Augmented Reality (Ar) Sebagai Teknologi Interaktif Dalam Pengenalan Benda Cagar Budaya Kepada Masyarakat. Simetris: Jurnal Teknik Mesin, Elektro Dan Ilmu Komputer, 8(2), 807. https://doi.org/10.24176/simet.v8i2.1614

[Indonesian]

Honggowiyono, P. (2015). Pertumbuhan dan Perkembangan Peserta Didik. Malang: Gunung Samudra. [Indonesian]

Indonesian Law No.20 of (2003). the National Education System.

Kovalchick, A., \& Dawson, K. (2004). Education E Technology: An Encyclopedia. California: ABCCLIO.

Mustaqim, I., \& Kurniawan, N. (2017). Pengembangan Media Pembelajaran Berbasis Augmented Reality. Jurnal Pendidikan Teknik Elektro, 1(1), 36-48. https://doi.org/10.21831/jee.v1i1.13267 [Indonesian]

Pachler, N., Bachmair, B., \& Cook, J. (2010). Mobile Learning. New York: Springer. https://doi.org/10.1007/978-1-4419-0585-7

Rayanto, Y. H., \& Sugianti. (2020). Penelitian Pengembangan Model ADDIE \& R2D2 Teori $\mathcal{E}$ Praktek. Kota Pasuruan: Lembaga Academic \& Research Institute.

Sari, P. (2019). Analisis terhadap kerucut pengalaman Edgar Dale dan keragaman gaya belajar untuk memilih media yang tepat dalam pembelajaran. Mudir: Jurnal Manajemen Pendidikan, I(1), 58-78. Diperoleh dari https://ejournal.insud.ac.id/index.php/MPI/arti cle/view/27 [Indonesian]

Sugiyono. (2015). Metode Penelitian \& Pengembangan. Bandung: Alfabeta. [Indonesian] 